Research Article

\title{
Using Benthic Diatom to Assess the Success of Batch Culture System Phytoremediation Process of Water Irrigation
}

\author{
Catur Retnaningdyah, Endang Arisoesilaningsih \\ Department of Biology, Faculty of Mathematics and Natural Sciences, Brawijaya University, Malang 65145, \\ Indonesia
}

Article history:

Submission October 2017

Revised July 2018

Accepted August 2018

*Corresponding author:

E-mail:

caturretnaningdyah@gmail.com

\begin{abstract}
Diatoms or phytobenthic are often used as bio-indicators of water quality in freshwater ecosystems such as rivers, but have never been used for monitoring the quality of artificial water ecosystems. The objective of this research is to use the diatom as a bioindicator for measurement the success of phytoremediation process of irrigation water that has status hyper-eutrophic and is polluted from organic materials using polyculture of various local hydromacrophytes through batch culture system. This experimental study was conducted in a greenhouse through planting some local emergent, submerged and floating leaf hydromacrophytes on a $30 \mathrm{~L}$ bucket with a given substrate from sand and gravel. The experiment used a completely randomized design with two treatment included phytoremediation model and control in the form of substrate without hydromacrophyte which repeated three times at the same time. The success of phytoremediation model was determined through some biotic diatoms indices (Percentage Pollution Tolerant Value/\%PTV, Tropical Diatom Index/TDI and Shannon Wiener Diversity Index) as bioindicator and the improved water physics chemical quality on days 0 , six, and 13 after incubation. The results showed that phytoremediation process using polyculture hydromacrophytes through batch culture system for 13 days significantly improving the quality of irrigation water. Based on some biotic diatom indices, the water was improved from heavily organic pollution to moderately organic pollution (\%PTV), from hypereutrophic to become eutrophic (TDI) and from moderately polluted become slightly polluted (Shannon Wiener Diversity Index). This results also supported from water physico-chemical parameters. Polyculture of some local hydromacrophytes for six days significantly decreased the organic matter content of irrigation water was reflected from the decrease concentration of Biochemical Oxygen Demand/BOD (14.79 mg/L to $3.61 \mathrm{mg} / \mathrm{L})$, Total Suspended Solid/TSS (14.6 mg/L to $0.08 \mathrm{mg} / \mathrm{L})$, turbidity (19.97 NTU to 1.46 NTU), nitrate $(1.44 \mathrm{mg} / \mathrm{L}$ to $0.03 \mathrm{mg} / \mathrm{L})$, orthophosphate $(0.24 \mathrm{mg} / \mathrm{L}$ to 0.042 $\mathrm{mg} / \mathrm{L})$, Total Kjeldahl Nitrogen (TKN) $(0.93 \mathrm{mg} / \mathrm{L}$ to $0.68 \mathrm{mg} / \mathrm{L})$, and free chlorine $(0.09 \mathrm{mg} / \mathrm{L}$ to $0.05 \mathrm{mg} / \mathrm{L})$, while concentration of Chemical Oxygen Demand (COD) decreased significantly 13 days after incubation from $48.3 \mathrm{mg} / \mathrm{L}$ to18.2 $\mathrm{mg} / \mathrm{L}$.
\end{abstract}

Keywords: Benthic diatom, phytoremediation, polyculture, water irrigation

\section{Introduction}

The existence of an organism varies in different places. This difference is due to the water quality that can affect the composition of the species. Species that can survive in polluted conditions can be used as biological indicators. Some benthic organisms are often used as indicator species for river pollution [1]. Periphytons or more commonly known as aufwuchs or attached benthic algae are groups of various organisms that grow or live on the free surface of objects that float and or sink in water such as plants, wood, stones and so on. Periphytons are generally treated as benthos, but some organisms may be part of the plankton. Pe

How to cite:

Retnaningdyah C, Arisoesilaningsih E (2018) Using Benthic Diatom to Assess the Success of Batch Culture System Phytoremediation Process of Water Irrigation. Journal of Tropical Life Science 8 (3): 259 - 268. doi: 10.11594/jtls.08.03.08 
riphytons have been widely used as bioindicators $[2,3,4]$. The advantages of use periphytons as an indicator of contamination is due to their abundance, is easy to find, collect and identify, and they have different responses to various contaminants. One of the periphyton groups often used as a bioindicator of water quality is the algae of the diatoms group [3]. Diatoms are often used as bio-indicators of water quality in freshwater ecosystems such as rivers, but have never been used for monitoring the quality of artificial water ecosystems (pond or bucket) that had been polluted. Trophic diatom index (TDI), percentage pollution tolerant values (\%PTV) and diversity index are some of biotic indices be used to indicate the level of eutrophication, organic pollution and level of toxic pollution [5].

The freshwater ecosystem in Indonesia, especially surface water sources in general has been polluted due to industrial activities as well as agricultural and settlement $[6,7,8,9]$. This surface water is the main source of irrigation water. Indonesia today, there is approximately 5 million ha of irrigated rice fields [6]. The irrigation water is distributed to the farm plot with the quantity and quality of water has been adapted to the needs of the cultivated crops, and flows the excess water to other places so it is not to damage the plants. Indonesia government have targeted a Healthy Indonesia program in 2025. Because of many obstacles, problems and complaints related to the intensification of agriculture, so the farm switched back to traditional organic farming. One of the problems faced is the provision of clean water irrigation. The existing irrigation water generally has been contaminated by pesticide residues and synthetic fertilizers. The use of synthetic pesticides in order to increase food production also has a negative impact on the environment. Synthetic pesticide residue is one of the materials that is toxic in the waters [10].

The polluted water can be controlled by phytoremediation process. Hidrophytes and riparian vegetation in the river or irrigation channels could show a significant role to reduce eutrophication risk and also promoted degradation of toxic residual pesticides accumulated from agriculture ecosystem [11]. The result of research in laboratory experiment has proved that some hidromacrophytes such as Azolla sp., Hydrilla verticillata, Limnocharis flava, Marsilea crenata, Equisetum ramosissium, Typha angustifolia, Scirpus grossus, and Lymnocharis flava in monoculture or polyculture showed high potential as remediator agent of nitrate and phosphate in aquatic ecosystem [12, $13,14,15]$. However, the successful application of hidrophytes and riparian vegetation to reduce the residual content of synthetic pesticides is unknown.

Based on the above description and also in order to guarantee the availability of irrigation water which is free from pesticide residue of synthetic and have good quality to support organic farming, hence this research purpose is to determine the effectiveness of phytoremediation technology from synthetic pesticide residue was done in batch culture system using polyculture of emergent, submerged and floating leaf local hydromacrophytes which are performed on a laboratory scale in a greenhouse. The success of the phytoremediation process is determined by monitoring the improvement of water quality as reflected by some biotic indices of diatom as bioindicator of water quality and some physico-chemical water parameters.

\section{Material and Methods Research design}

The true-experimental research was conducted in a greenhouse of Biology Department, Brawijaya University. Water quality measurement was conducted in laboratory of Ecology and Animal Diversity Department of Biology Faculty of Mathematics and Natural Sciences, Brawijaya University, Malang. This true experiment using a completely randomized design [16]. The treatment or independent variables were hydromacrophytes species (with and without) and dependent variables were community structure, diversity, some biotic indices of diatoms as a bioindicator of water quality and water physico-chemical parameters. Some of local Hydromacrophytes in the phytoremediation process were emergent macrophytes (Scirpus sp., Acorus calamus, M. crenata), floating leaf macrophytes (I. aquatica, Azolla sp.), and submerged macrophytes (Valisneria sp., H. verticilata). This hydromacrophytes were planted in a $30 \mathrm{~L}$ bucket with a given substrate from sand with height $5 \mathrm{~cm}$ and gravel with height $10 \mathrm{~cm}$. The control treatment in the form of substrate without hydromacrophyte. Each treatments repeated three times at the same time. The planting of hydromacrophytes in each treatment basin is $25 \%$ of the 

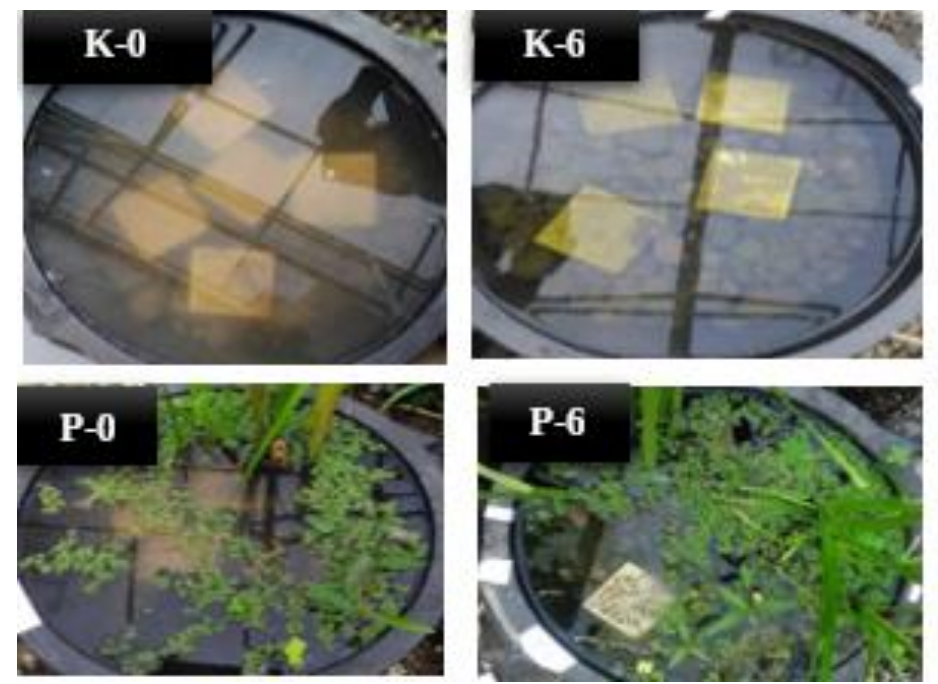

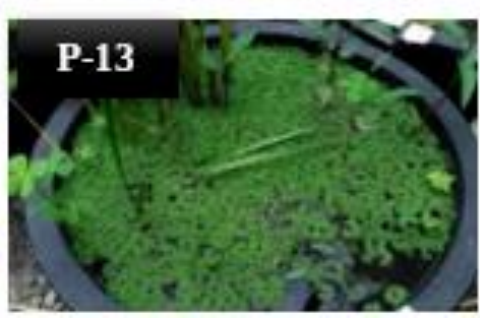

Figure 1. The growth of hydromacrophytes in the batch culture system of phytoremediation process. Note: $\mathrm{K}=$ control treatment without hydromacrophytes; $\mathrm{P}$ = treatment of polyculture from emergent, submerged and floating leaf hydromacrophytes $0,6,13$ days after incubation

Table 1. Water physico-chemical parameters were measure in this research

\begin{tabular}{llll}
\hline No. & \multicolumn{1}{c}{ Parameters } & \multicolumn{1}{c}{ Unit } & \multicolumn{1}{c}{ Methods } \\
\hline 1. & $\mathrm{pH}$ & - & pHmeter \\
2. & Dissolved Oxygen (DO) & $\mathrm{mg} / \mathrm{L}$ & Digital Oxygenmeter \\
3. & Turbidity & $\mathrm{NTU}$ & Turbidimeter \\
4. & Total Suspended Solid (TSS) & $\mathrm{mg} / \mathrm{L}$ & Gravimetric \\
5. & Nitrate & $\mathrm{mg} / \mathrm{L}$ & Brucine methods \\
6. & Dissolved phosphates (Orthophosphate) & $\mathrm{mg} / \mathrm{L}$ & Stannous Chloride methods \\
7. & Bicarbonate & $\mathrm{mg} / \mathrm{L}$ & Titrimetry \\
8. & BOD & $\mathrm{mg} / \mathrm{L}$ & Potentiometri \\
9. & COD & $\mathrm{mg} / \mathrm{L}$ & Spectrophotometry \\
10. & Free Chlorine & $\mathrm{mg} / \mathrm{L}$ & Titrimetry \\
11. & Total Kjeldahl Nitrogen & $\mathrm{mg} / \mathrm{L}$ & Macro Kjeldahl \\
\hline
\end{tabular}

surface area. In this experiment, simultaneously with planting of hydromacrophytes, we also laying of artificial diatom substrate from ceramics $5 \times 5$ $\mathrm{cm}^{2}$ as much as 3 pieces in each treatment. The hydromacrophytes were maintained until steady growth and then given irrigation water that has been contaminated with organic and toxic materials. The monitoring of some biotic indices and diversity of diatom and also water physico-chemical quality monitoring performed in each treatment at day 0 (a moment after planting), day 6 and day 13 after incubation.

Monitoring water quality based on diatom as bioindicator and water physico-chemical parameter

The success or effectiveness of the phytoremediation process was known from some biotic indices of diatoms included diversity index, trophic diatom index (TDI) and percentage pollution toler- ant values (\%PTV) and also monitoring of several water physico-chemical parameters. We were measured at day 0 (a moment after planting), day 6 and day 13 after incubation. Diatoms were obtained from artificial substrate (ceramics $5 \times 5$ $\mathrm{cm}^{2}$ ) had been installed in early treatment together with the time planting of hydromacrophytes. Diatom sampling was done by cleansing each side of the artificial substrate with a brush and watered with water and then inserted into a flacon bottle and preservatives in 10 drops of $4 \%$ formaldehyde and 5 drops of saturated $\mathrm{CuSO}_{4}$. Diatom identification based on identification book $[17,18]$. The physico-chemical parameters were measured in this research included $\mathrm{pH}$, dissolved oxygen (DO), turbidity, total suspended solid (TSS), nitrates and dissolved phosphates (orthophosphates), bicarbonate, BOD, COD, free chlorine and Total Kjeldahl Nitrogen (TKN). Those parameters were de- 


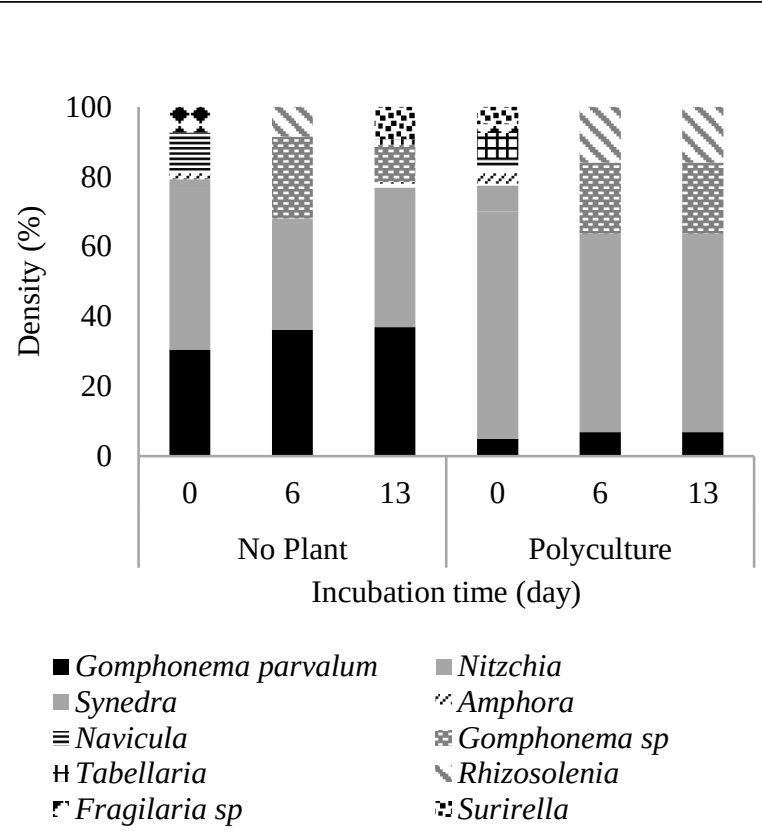

(a)

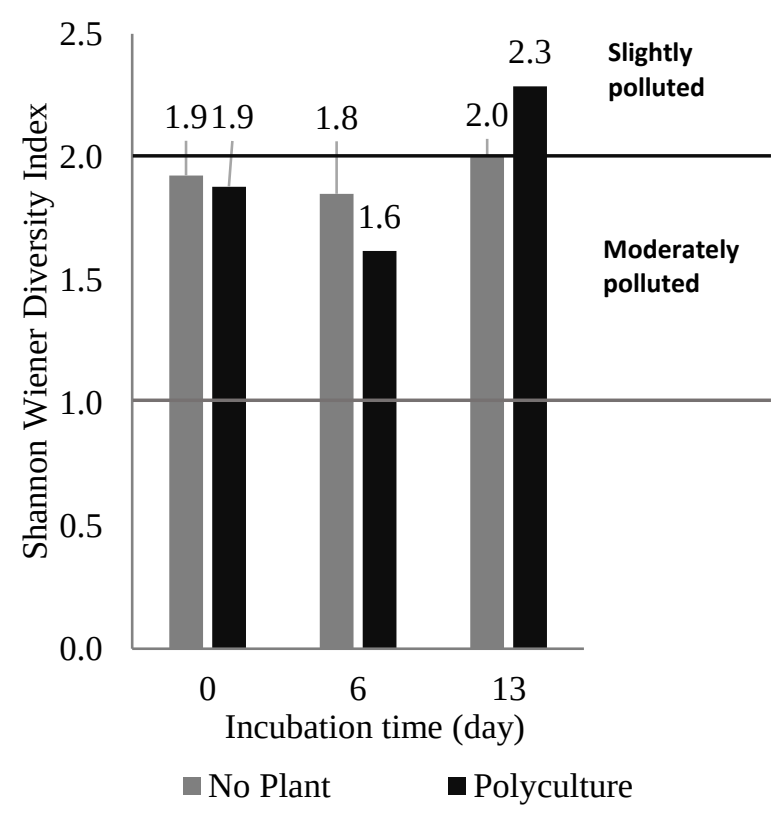

(b)

Figure 2. Relative density (a) and diversity index (b) of diatom the phytoremediation process through batch culture system using polyculture of emergent, submerged and floating leaf hydromacrophytes

termined based on standard methods for the examination of water [19] as can be seen in Table 1. The monitoring of water quality and community structure of diatom was performed in each treatment which plant coverage achieved $50-75 \%$ of the basin area (Figure 1).

\section{Data analyses}

The data of diatoms (density and taxa richness) then be used to determined Shannon Wiener diversity index, trophic diatom index (TDI) and the percentage pollution tolerant values (\%PTV) as a bioindicator of water quality in the ponds after phytoremediation process [5, 20, 21]. The difference of water quality between the ponds was determined by descriptively statistical using Excel programs.

\section{Results and Discussion}

The effectiveness of batch culture system phytoremediation using polyculture of emergent, submerged and floating leaf local hydromacrophytes for improving polluted irrigation water based on Diatom biotic indices

The quality of water irrigation used in this treatment had polluted by organic and toxic material. Polyculture of some local floating leaf, submerged and emergent hydromacrophytes (Scirpus sp., A. calamus, M.crenata, I. aquatica, Azolla sp.,
Valisneria sp., and $H$. verticilata) which grown in a basin with sand and gravel substrates in the phytoremediation process using batch culture system capable to increase the irrigation water quality. It could be seen from some biotic indices and the diversity index of diatoms. Improvement of water quality is reflected in the increasing value of diatom diversity index and the decreasing value of TDI and percentage of PTV) as a bioindicator of water quality [22]. In this research, the result of identification and counting of each diatom species abundance in the artificial substrate which was installed together with the planting of hydromacrophytes in the batch culture system then be used for calculating relative density and Shannon Wiener diversity index (Figure 2) and also index biotic of TDI and \%PTV (Figure 3). The result of identification and calculating the density of diatom showed that there were found 11 taxa of diatom in the batch culture system were used in this research. Gomphonema parvalum and Nitzchia sp. were dominan in the treatments without the plant, and only Nitzchia sp. dominan in the treatment polyculture of some local floating leaf, submerged and emergent hydromacrophytes (Figure 2). In generally, there was a decrease in value of Nitzchia sp. 6 and 13 days after incubation. G. parvalum and Nitzschia palea were tolerant spe- 


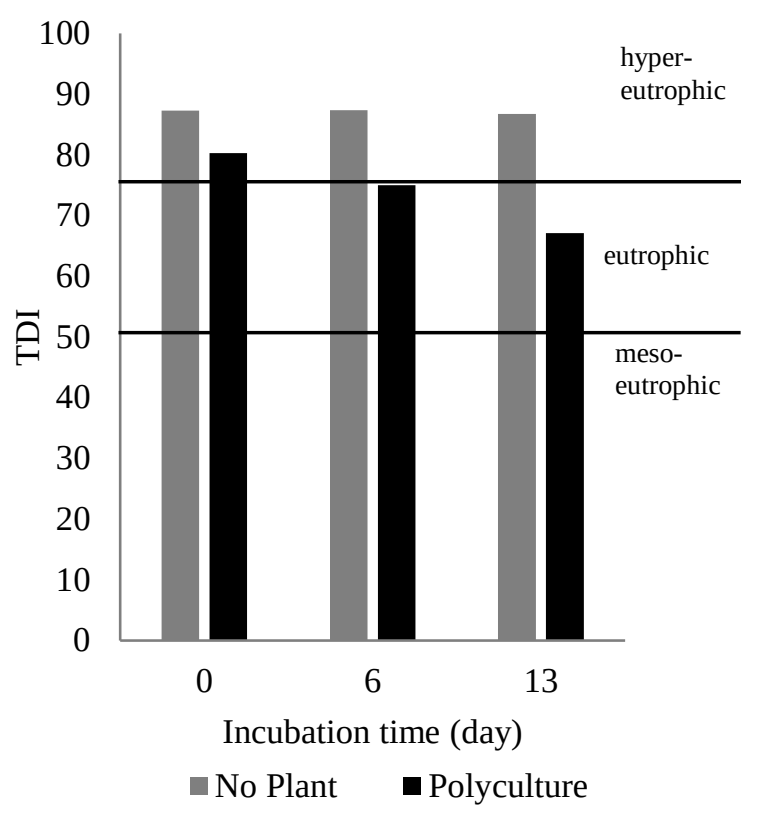

(a)

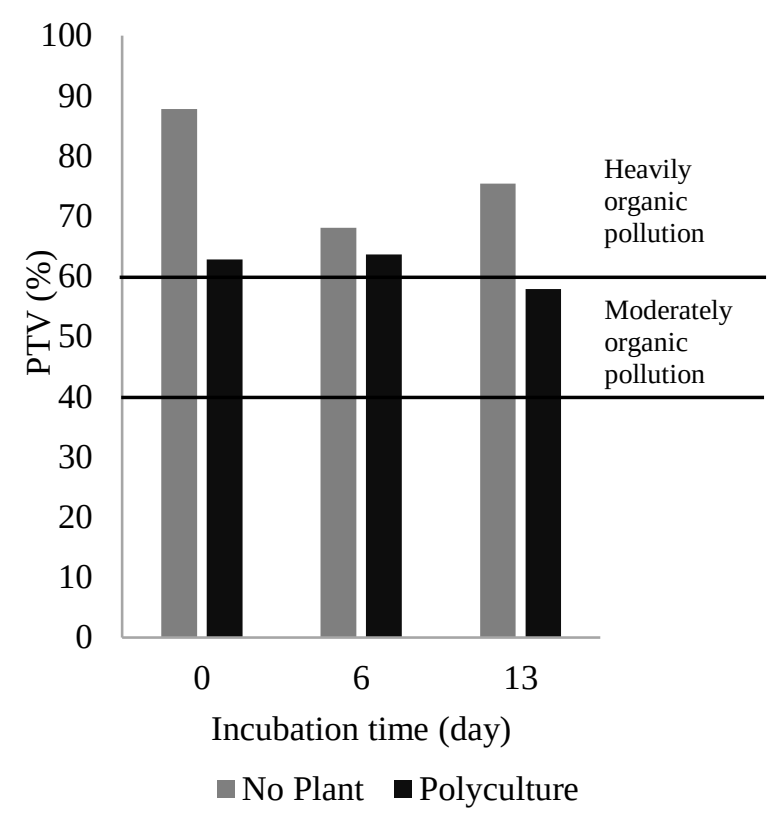

(b)

Figure 3. Relative density (a) and diversity index (b) of diatom the phytoremediation process through batch culture system using polyculture of emergent, submerged and floating leaf hydromacrophytes

cies of organic pollution [21] and a kind of bioindicator of high nutrient levels (eutrophic) and organic pollution in the freshwater [23, 24]. Therefore, decreasing the abundance of G. parvalum in polyculture treatment (Figure 2A) indicated an increase in water quality of water irrigation used in this treatment or could be said that process phytoremediation using polyculture hydromacrophytes has been successful.

Improvement of water quality as a result of phytoremediation process using polyculture hydromacrophytes in this study not only reflected from decreasing the density of G. parvalum but also be seen from increasing value of Shannon Wiener diversity index and decreasing value of TDI and \%PTV [5, 20, 21, 22]. The increasing value of Shannon Wiener diversity index of diatom increased from 1.9 to $2.0-2.3$ after phytoremediation process for 13 days (Figure 2B). This is indicated that the phytoremediation process in this research has succeeded in improving the water quality from moderately toxic polluted being lightly toxic contaminated. Similarly, based on the value of TDI (Figure 3A), the status of water changed from hyper-eutrophic (TDI $>80$ ) to eutrophic (TDI $=67)$ in polyculture treatments. Based on the organic pollution level which can be indicated by the percentage PTV (Figure 3B), the process of phytoremediation for 13 days incuba- tion could increase the quality of water from heavily organic pollution (PTV $=63-88 \%$ ) to some moderately organic pollution (PTV $=57.8 \%$ ).

The polyculture of Scirpus sp., A. calamus, $M$. crenata, I. aquatica, Azolla sp., Valisneria sp., and $H$. verticilata in this research capable to improve the irrigation water quality from moderately toxic polluted being lightly toxic polluted, from hypereutrophic waters become eutrophic waters and decreasing the level of organic pollution from heavily organic pollution become moderately organic pollution. This role of hydromacrophytes as a filter of sediment, toxic substances, phosphorus and nitrogen, and an organic pollutant of the water. The use of hydromacrophytes to reduce $\mathrm{N}$ and $\mathrm{P}$ as well as a toxic pollutant and organic matter in polluted water bodies has been widely recommended by other researchers $[7,11,12,22,25,26$, $27,28]$.

The effectiveness of batch culture system phytoremediation using polyculture of emergent, submerged and floating leaf local hydromacrophytes for improving polluted irrigation water based on physicochemical quality

Polyculture of some local floating leaf, submerged and emergent hydromacrophytes in the phytoremediation process using batch culture system for six days in this experiment could signifi- 

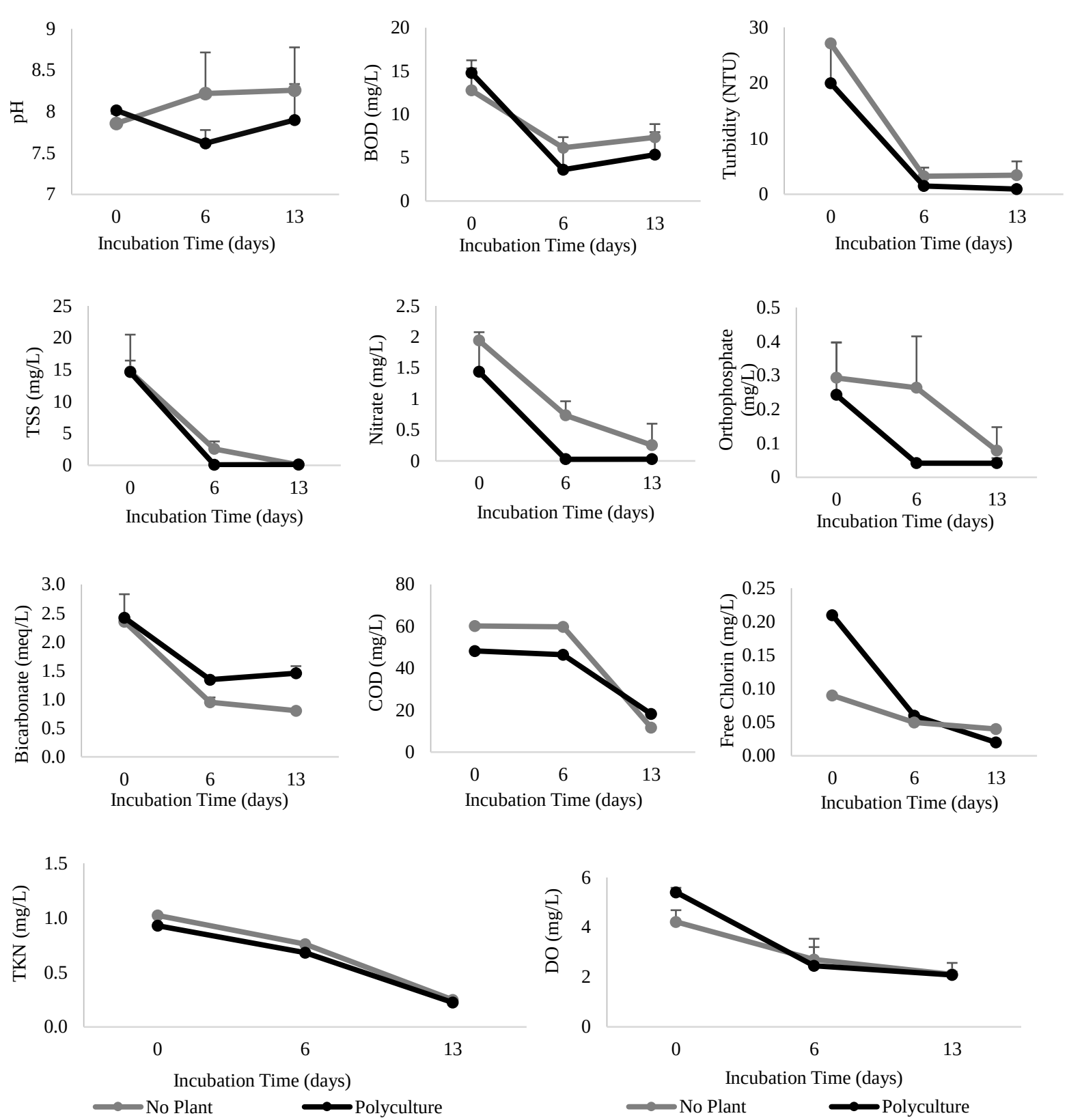

Figure 4. The average of some physico-chemical irrigation water quality in the phytoremediation process through batch culture system using polyculture of emergent, submerged and floating leaf hydromacrophytes

cantly reduce the levels of BOD, turbidity, TSS, nitrate, orthophosphate and bicarbonate. That phytoremediation process could significantly reduce the concentration of free chlorine, COD and TKN after incubation for 13 days. The value of $\mathrm{pH}$ tends to be neutral, however the value of dissolved oxygen did not yet able to increase (Figure 4).

The concentration of dissolved oxygen in the phytoremediation process for 13 days was not to be able to increase. The levels of DO at the moment after planting hydromacophytes was 4.22 $\mathrm{mg} / \mathrm{L}$ in the control treatment (without plant) and $5.41 \mathrm{mg} / \mathrm{L}$ in the polyculture treatment. Phytoremediation process for 13 days reduces the DO concentration to $2.11 \mathrm{mg} / \mathrm{L}$ in the control treatment and $2.01 \mathrm{mg} / \mathrm{L}$ in the polyculture treatment. However, this concentration still meets the quality standard of water class IV for irrigation based on the provision of Indonesia government regulation No. 82 of 2001 on water quality management and water pollution control. Hydromacrophytes were used for phytoremediation process is a combina- 
tion of hydromacrophytes of floating leaf, submerged and emergent hydromacrophytes. Submerged hydromacrophytes have an advantage because of oxygen as a result of photosynthesis directly dissolved in water. Nevertheless, improvements in water quality in this research is still not optimal because the DO value as a result of the phytoremediation process was still low. This is likely due to the smaller number of hydromacrophytes had been planted, so the oxygen as the result from photosynthetic process only can be used for respiration of all water organism in the basin.

The filter of sediment through phytoremediation process for 6 days in this research has been able to significantly reduce the value of turbidity in the irrigation water from 27.1 NTU to 3.24 NTU in the control treatment without plant and from 19.97 NTU to 1.46 NTU in the polyculture treatment. This shows that planting of hydromacrophytes has an impact on the sedimentation process of suspended solids in irrigation water. Polyculture of some local floating leaf, submerged and emergent hydromacrophytes for 6 days have also reduced the levels of total suspended solids (TSS) significantly from $14.6 \mathrm{mg} / \mathrm{L}$ to $0.08 \mathrm{mg} / \mathrm{L}$. This value is significantly different with control treatment without plant that capable to reduce TSS from $14.69 \mathrm{mg} / \mathrm{L}$ to $2.55 \mathrm{mg} / \mathrm{L}$. The value of TSS is in compliance with the quality standards of Class I and II based on Indonesia government regulation with a maximum limit of level $50 \mathrm{mg} / \mathrm{L}$.

This phytoremediation process besides being able to filter suspended solids is also able to reduce nutrients such as phosphorus and organic nitrogen in the water $[25,26]$. The residue of synthetic fertilizers in irrigation water can be reflected in the levels of $\mathrm{P}$ and $\mathrm{N}$ in the waters either in the form of dissolved phosphate or orthophosphate, TKN and nitrate. Planting of some local floating leaf, submerged and emergent hydromacrophytes in phytoremediation basin for 6 days able to reduce levels of nitrates and phosphates dissolved in the waters significantly and there was needed incubation for 13 days to reduce the value of TKN (Figure 4). Phytoremediation process using polyculture hydromacrophytes for 6 days has successfully decreased the levels of nitrates in the irrigation water from $1.44 \mathrm{mg} / \mathrm{L}$ to $0.03 \mathrm{mg} / \mathrm{L}$, and treatment without plants capable to reduce nitrat from 1.94 $\mathrm{mg} / \mathrm{L}$ to $0.73 \mathrm{mg} / \mathrm{L}$. Similarly, levels of dissolved phosphates or orthophosphate decreased from
$0.24 \mathrm{mg} / \mathrm{L}$ to $0.04 \mathrm{mg} / \mathrm{L}$ in the polyculture treatment and from $0.29 \mathrm{mg} / \mathrm{L}$ to $0.26 \mathrm{mg} / \mathrm{L}$ in the control treatment without plant. The value of TKN decrease from $0.93 \mathrm{mg} / \mathrm{L}$ to $0.22 \mathrm{mg} / \mathrm{L}$ in the polyculture treatment and from $1.02 \mathrm{mg} / \mathrm{L}$ to 0.25 $\mathrm{mg} / \mathrm{L}$ in the control treatment. The concentration of $\mathrm{NO}_{3}-\mathrm{N}$ less than $5 \mathrm{mg} / \mathrm{L}$ indicates have good quality and can be used for all agricultural crops. The quality standard of nitrate based on Indonesia government regulation No. 82/2001 is $10 \mathrm{mg} / \mathrm{L}$ for Class II. In addition to the plants species used in this study, several other hydromacrophytes such as L. flava, Fimbristylis globulosa, Vetiveria zizanoides, E. ramosissium, T. angustifolia, Azolla sp., Monochoria vaginalis, Ludwigia hyssopifolia, and Ludwigia adscendens has also been proven to reduce pollutants of dissolved $\mathrm{N}$ and $\mathrm{P}$ are derived from synthetic fertilizer and other materials on the scale of the greenhouse through a batch culture system [14, 15, 27, 29].

The existence of organic matter in the waters can be known from the parameter values of BOD and COD. BOD and COD are the levels of oxygen needed to degrade organic materials biologically (BOD) and chemically (COD). The irrigation water used in this research have concentration BOD 12.76 - $14.79 \mathrm{mg} / \mathrm{L}$ and COD 48.3 - $60.2 \mathrm{mg} / \mathrm{L}$. Polyculture of some local floating leaf, submerged and emergent hydromacrophytes for 6 days capable to reduce the value of BOD to $3.61 \mathrm{mg} / \mathrm{L}$ and bioremediation process without plant only capable to reduce BOD to $6.14 \mathrm{mg} / \mathrm{L}$. The maximum limits of BOD based on Indonesia government standard Class III for agriculture is $6.0 \mathrm{mg} / \mathrm{L}$. So, it can be met if the irrigation water is controlled by phytoremediation process. COD reflected the concentration of toxic material in the water. Phytoremediation using polyculture hydromacrophytes for 6 days was not capable to reduce the value of COD significantly, but the phytoremediation process using polyculture of hydromacrophytes for 13 days capable to reduce COD from $48.3 \mathrm{mg} / \mathrm{L}$ to 18.2 $\mathrm{mg} / \mathrm{L}$, and treatment without plant capable to reduce COD from $60.21 \mathrm{mg} / \mathrm{L}$ to $11.75 \mathrm{mg} / \mathrm{L}$. This concentration had met the Indonesia government standards Class II for agriculture (maximum 25 $\mathrm{mg} / \mathrm{L})$. Therefore, this phytoremediation model has succeeded in reducing the COD level to meet the standards Class II, although the BOD content only meets the standards Class III.

The existence of pesticide residues can be re 

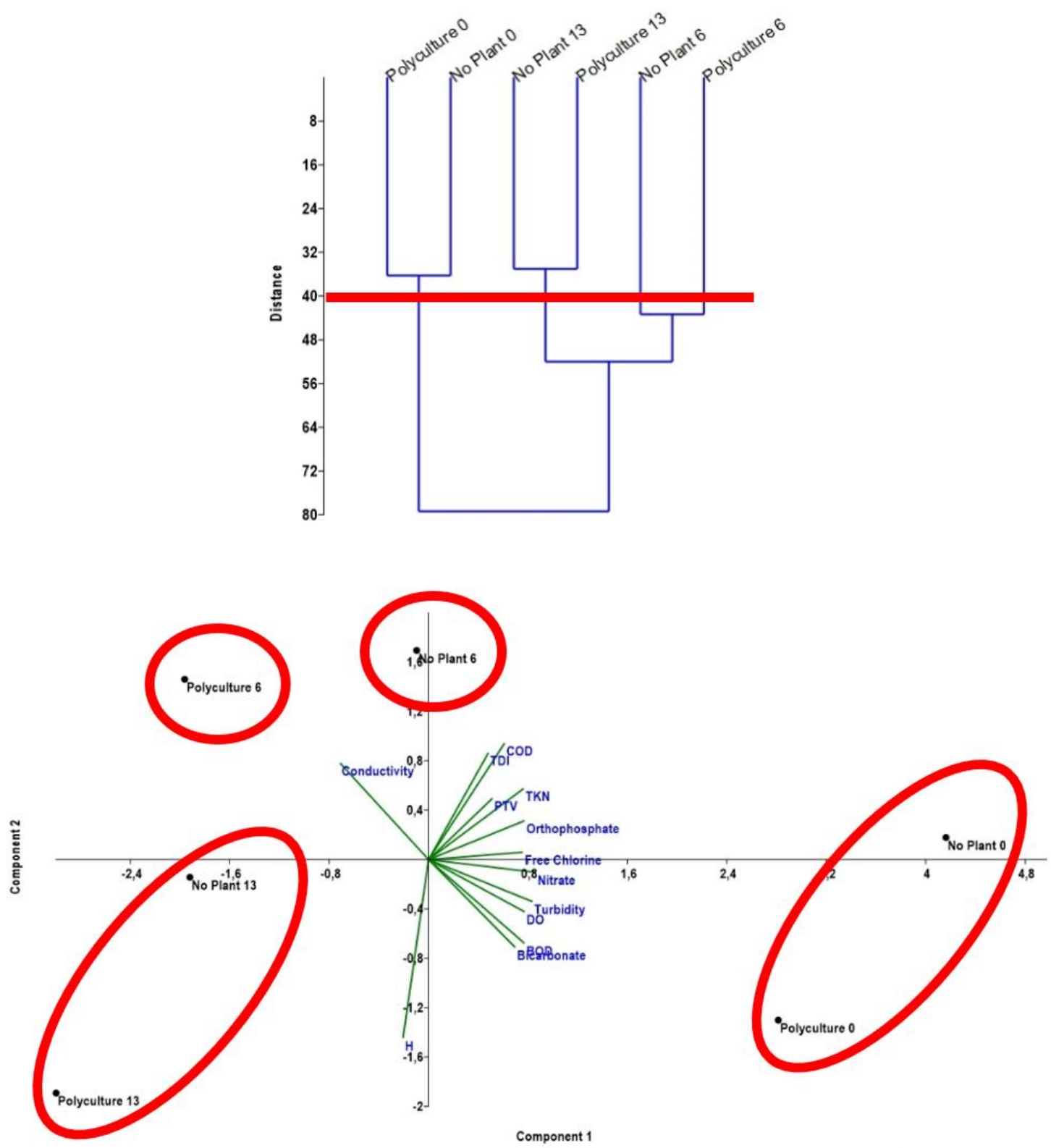

Figure 5. Grouping the quality of water in the treatment based on some physico-chemical parameters and diatom biotic indices using cluster analyses and biplot from principal component analyses (PCA)

flected from COD and free chlorine. The irrigation water used in this treatment have a concentration of free chlorine $0.09-0.21 \mathrm{mg} / \mathrm{L}$. Bioremediation process whether or not with hydromacrophytes for 13 days capable to reduce free chlorine to $0.02-$ $0.04 \mathrm{mg} / \mathrm{L}$. This value had met the Indonesia government standards Class II for agriculture (maximum $0.03 \mathrm{mg} / \mathrm{L}$ ). Hydromacrophytes has a contribution to increased infiltration of water into the soil and also expected to be utilized in the phytoremediation process to degrade toxic contaminants such as fertilizer and toxic pesticide residues were applied to agricultural land [11].
Comparison of irrigation water quality without and with phytoremediation process through batch culture system

The effectiveness of phytoremediation process in batch culture system using polyculture of some local floating leaf, submerged and emergent hydromacrophytes (Scirpus sp., A. calamus, M. crenata, I. aquatica, Azolla sp., Valisneria sp., and $H$. verticilata) which grown in basin with sand and gravel substrates can be seen from the improvement of water quality on the 6 and 13 days after incubation compared with the day 0 that is shortly after planting. If the phytoremediation process can 
effectively improve the water quality, there will be significant differences in physical-chemical that can be reflected from decreasing value of pollutant parameters, increasing value of diatom diversity index and the decreasing value of TDI and \%PTV as a bioindicator of water quality on 6 and 13 days after incubation. The differences in water quality can generally be seen in the result of water quality data analysis based on Cluster and Biplot analysis as seen in Figure 5. Based on cluster analysis, it can be seen that there was a significant difference in the water quality between day 0 and day 6 as well as 13 after incubation. Based on Biplot analysis it can be seen that water quality shortly after treatment is characterized by high values of all parameters of water physico-chemical parameter, TDI, \%PTV and low value of diatom diversity index. It is indicated that before phytoremediation processes the irrigation water quality had polluted by the organic and toxic material. Phytoremediation process for six days could significantly reduce the levels of BOD, turbidity, TSS, nitrate, orthohosphate, bicarbonate and also decrease the toxic pollutant based on diatoms diversity index. There was difference ability between polyculture phytoremediation process and treatment without hydromacrophytes at 6 days incubation. Phytoremediation process using polyculture of hydromacrophytes was more effective compared with treatment without plants. The phytoremediation process and also treatment without hydromacrophytes (only using substrates from sand and gravel) more effective or could significantly reduce the concentration of free chlorine, COD and TKN and also TDI which reflected in organic pollution become moderate and decreasing status trophic (\%PTV) become eutrophic after incubation for 13 days. Therefore, it can be concluded that the phytoremediation process in this research treatment has been able to improve water quality based on water physico-chemical parameter and some diatom biotic indices as a bioindicator of water quality.

\section{Conclusion}

Polyculture of some local floating leaf, submerged and emergent hydromacrophytes in batch culture system for 6-13 days has been able to improve the quality of water in irrigation canals that was reflected from the value of diatom diversity and some biotic indices of diatoms as bioindica- tors and also reducing the value of some water physico-chemical parameters. However, it is still necessary to improve the phytoremediation process that can increase the levels of dissolved oxygen to meet the standards has been set by the government.

\section{Acknowledgment}

This research is a part of institutional research grant 2017 (PTUPT 2017) budget year that are funded by Directorate General of Higher Education of Indonesia through the University of Brawijaya, so we would like to say thank you very much to National Education Ministry of Indonesia and Rector of Brawijaya University.

\section{References}

1. Hynes HBN (1974) The biology of polluted water. Cambridge, Liverpool Univ. Press.

2. Herbst DB, Blinn DW (2007) Preliminary index of biological integrity (IBI) for Periphyton in the Eastern Sierra Nevada, California (Research Report). California, California University.

3. Roubeix V, Mazzella N, Schouler L et al. (2011) Variations of periphytic diatom sensitivity to the herbicide diuron and relation to species distribution in a contamination gradient: Implications for biomonitoring. Journal of Environmental Monitoring 13 (6): 1768 - 1774. doi: 10.1039/C0EM00783H.

4. Mbao EO, Kitaka N, Oduor SO, Kipkemboi J (2013) Periphyton as inorganic pollution indicators in Nyangores Tributary of the Mara River in Kenya. International Journal of Fisheries and Aquatic Sciences 2 (4): 81 - 93.

5. Wu N, Schmalz B, Fohrer N (2014) Study progress in riverine Phytoplankton and its use as bio-indicator - a Review. Austin Journal of Hydrology 1 (1): 9.

6. Kurnia G (2001) Efisiensi air irigasi untuk memperluas areal tanam. prosiding seminar nasional multifungsi lahan sawah. In Proceedings of Seminar Nasional Multifungsi Lahan Sawah: 1 May 2001; Bogor. Edited by Agus F. Bogor, Balai Penelitian Tanah. $137-142$.

7. Retnaningdyah C, Arisoesilaningsih E (2013) Ecological significance of irrigation channel riparian to improve benthic macroinvertebrate diversity. Oral presentation on International Conference on Global Resource Conservation (ICGRC): 7 - 8 February 2013. Malang, Indonesia.

8. Rahmawati R, Retnaningdyah C (2015) Studi kelayakan kualitas air minum delapan mata air di Kecamatan Karangploso Kabupaten Malang. Biotropika: Journal of Tropical Biology 3 (1): $50-54$.

9. Wimbaningrum R, Indriyani S, Retnaningdyah C, Arisoesilaningsih E (2016) Monitoring water quality using biotic indices of benthic macroinvertebrates along surfaces water ecosystems in 
some tourism areas in East Java, Indonesia. Journal of Indonesian Tourism and Development Studies 4 (2): 81 - 90. doi: 10.21776/ub.jitode.2016.004.02.06.

10. Daam MA, Brink PJV (2010) Implications of differences between temperate and tropical freshwater ecosystems for the ecological risk assessment of pesticides. Ecotoxicology 19 (01): 24 - 37. doi: 10.1007/s10646-009-0402-6.

11. Chaudhry Q, Schroder P, Werck-Reichhart D et al. (2002) Prospects and limitations of phytoremediation for the removal of persistent pesticides in the environment. Environmental Science and Pollution Research 9: 4 - 17. doi: 10.1007/BF02987313.

12. Retnaningyah C, Suharjono (2010) Optimizing of Bioremediation Techniques from water in Sutami Reservoir Malang as a Result of Phosphate and Nitrate contamination and Blooming of Microcystis Using Microbes and Hydromacrophytes. National Competitive Grant Research Reports Funding by Indonesia Government (Report).

13. Vidayanti V, Retnaningdyah C, Suharjono (2012) The Capability of Equisetum ramosissium and Typha angustifolia as phytoremediation agents to reduce nitrate-phosphate pollutants and prevent Microcystis blooming in fresh water ecosystem. Journal of Tropical Life Science 2 (3): 126 - 131. doi: 10.11594/jtls.02.03.12.

14. Sundari AS, Retnaningdyah C, Suharjono (2013) The Effectiveness of Scirpus grossus and Limnocharis flava as fitoremediation agents of nitrate-phosphate to prevent Microcystis blooming in fresh water ecosystem. Journal of Tropical Life Science 3 (1): 28 - 33. doi: 10.11594/jtls.03.01.05.

15. Prahardika BA, Retnaningdyah C, Suharjono (2013) The Control of Microcystis spp. bloom by combining indigenous denitrifying bacteria from Sutami Reservoir with Fimbristylis globulosa and Vetiveria zizanoides. Journal of Tropical Life Science 3 (1): 52 - 57. 10.11594/jtls.03.01.09.

16. Krebs CJ (1989) Ecological methodology. New York, Harper and Row Publ.

17. Edmondson WT (1959) Freshwater biology. New York, Second Ed. John Wiley and Sons Inc.

18. Prescott GW (1978) How to know the fresh water algae. 3rd Ed. Wm.C. Iowa, Brown Company Publisher.

19. Clesceri LS, Greenberg AE, Eaton AD (1998) Standard methods for the examination of water and waste water. 20th Ed. American Public Health Association, Washington.

20. Kelly MG (1998) Use of the trophic Diatom index to monitor eutrophication in rivers. Water Research 32 (1): 236 - 242.
21. Kelly MG, Whitton BA (1995) The Trophic Diatom index: A new index for monitoring eutrophication in rivers. Journal of Applied Phycology 7 (4): 433 - 444. doi: 10.1007/BF00003802

22. Retnaningdyah C, Arisoesilaningsih E, Samino S (2017) Use of local Hydromacrophytes as phytoremediation agent in pond to improve irrigation water quality evaluated by Diatom Biotic Indices. Biodiversitas 18 (4): 1611 - 1617. doi: 10.13057/bio$\operatorname{div} / \mathrm{d} 180440$.

23. Onyema IC (2013) Phytoplankton bio-indicators of water quality situations in the Iyagbe Lagoon, South-Western Nigeria. Research Journal of Pharmaceutical, Biological and Chemical Sciences 4 (3): 639 - 652.

24. Singh UB, Ahluwalia AS, Sharma C et al. (2013) Planktonic indicators: A promising tool for monitoring water quality (earlywarning signals). Ecology, Environment and Conservation Paper 19 (3): 793 - 800.

25. Jayaweera MW, Kasturiarachchi JC (2004) Removal of nitrogen and phosphorus from industrial wastewater by phytoremediation using water hyacinth (Eichhornia crassipes (Mart.)Solms). Water Science and Technology 50 (6): 217 225. doi: 10.2166/wst.2004.0379.

26. Xiang W, Xiao EY, Rengel Z (2009) Phytoremediation facilitates removal of nitrogen and phosphorus from eutrophicated water and release from sediment. Environmental Monitoring and Assessment 157 (1 - 4): 277 - 285. doi: 10.1007/s10661008-0534-9.

27. Ivansyah K, Retnaningdyah C (2013) Potensi hidromakrofita lokal untuk peningkatan kualitas air irigasi tercemar pupuk NPK dengan sistem batch culture. Biotropika: Journal of Tropical Biology 1 (3): $80-84$.

28. Retnaningdyah C (2017) The improvement of the quality of polluted irrigation water through a phytoremediation process in a hydroponic batch culture system. In AIP Conference Proceedings 1908 of $8^{\text {th }}$ International Conference on Global Resource Conservation (ICGRC 2017): Green Campus Movement for Global Conservation: 19 - 20 July 2017; Malang. Edited by Salunkhe C, Kikuchi A, Govinda B et al. doi: 10.1063/1.5012703

29. Retnaningyah C, Suharjono, Budiman, Purnomo (2012) Control of Microcystis growth by Azolla sp. in combination with aerobic denitrifying bacteria indigenous from Indonesia reservoir. Oral Presentation on Malaysia International Biological Symposium 2012 (i-SIMBIOMAS 2012): 11 - 12 July 2012. Kuala Lumpur, Malaysia. 